\title{
Influence of Different Plant Densities and Mulches on Quality and Bio Chemical Parameters of Mango (Mangifera indica L.) cv. Alphonso
}

\author{
B.S. Sagar*, S.I. Athani, S. Raghavendra, Mallikarjun Awati, J.B. Gopali, \\ T.B. Allolli, Kulapati Hipparagi and Revanappa \\ Department of Horticulture, College of Horticulture, Bagalkot, University of Horticultural \\ Sciences, Bagalkot, 587-104 (Karnataka), India \\ *Corresponding author
}

\begin{tabular}{|l|}
\hline Ke y w or d s \\
High density, \\
Mulching and bio \\
chemical
\end{tabular}

\section{A B S T R A C T}

The experiment was carried out to know the effects of high density planting and different mulches on quality parameters of mango (Mangifera indica L.) cv. Alphonso at Regional Horticulture Research and Extension Centre, Dharwad (University of Horticultural Sciences, Bagalkot) during May - 2016 to June 2018. The maximum value of acidity content $(0.54 \%)$ was recorded in $D_{3} M_{1}(5.0$ x $5.0 \mathrm{~m}$ spacing and no mulch). Ascorbic acid of $41.22 \mathrm{mg} / 100 \mathrm{gm}$ was found maximum in the treatment of $\mathrm{D}_{1} \mathrm{M}_{1}(2.5 \times 2.5 \mathrm{~m}$ spacing and no mulch) and the maximum TSS of $23.55{ }^{0} \mathrm{~B}$ was observed in $\mathrm{D}_{4} \mathrm{M}_{3}(7.5 \times 5.0 \mathrm{~m}$ spacing and plastic mulch). The treatment $\mathrm{D}_{3} \mathrm{M}_{3}(5.0 \times 5.0 \mathrm{~m}$ spacing with plastic mulch) recorded the maximum amount of total sugar content $(13.99 \%)$, Reducing sugars of $5.12 \%$ was found maximum in the treatment $\mathrm{D}_{1} \mathrm{M}_{3}$, the maximum Non Reducing sugar content of $8.60 \%$ was recorded in $\mathrm{D}_{3} \mathrm{M}_{3}(5.0 \times 5.0 \mathrm{~m}$ spacing with plastic mulch) and maximum total chlorophyll of $2.29 \mathrm{mg} / \mathrm{g}$ was observed in $\mathrm{D}_{3} \mathrm{M}_{3}(5.0 \times 5.0 \mathrm{~m}$ spacing with plastic mulch), maximum carotenoid content (2.92) was noticed in $\mathrm{D}_{2} \mathrm{M}_{3}(5.0 \times 2.5 \mathrm{~m}$ spacing with plastic mulch) and proline content of $130.55 \mu \mathrm{g} / \mathrm{g}$ was found maximum in $\mathrm{D}_{4} \mathrm{M}_{2}$ treatment $(7.5 \times 5.0 \mathrm{~m}$ spacing with straw mulch).

\section{Introduction}

Mango (Mangifera indica L.) belonging to family Anacardiaceae. It is the most important commercially grown fruit crop of the country. It is called the king of fruits. India has the richest collection of mango cultivars. Cultivation of mango is believed to have originated in South East Asia and it is being cultivated in southern Asia for nearly six thousand years. The word 'Mangifera' is derived from the Tamil word Mangai and Fero means to bear. The word 'indica' means Indian and stands for the name of the species. The system of high density planting (HDP) has been successfully implicated in mango, since high density planting results in the better utilization of natural resources. In most of the 
regions, where mango is grown, solar radiation is abundant and thus productivity largely depends upon its efficient utilization. The system and density of planting need to be designed to intercept the solar radiation effectively. Mulching is the process or practice of covering the soil/ground to make more favourable condition for plant growth, development and efficient crop production. According to other mulches plastic mulches are completely impermeable to water; therefore it prevents direct evaporation of moisture from the soil and thus it reduce the water losses and soil erosion over the surface. Thus moisture is preserved for several days and increases the period between two irrigations (Anonymous, $2014^{[1]}$ and Biswas et al., 2015 $\left.{ }^{[2]}\right)$.

\section{Materials and Methods}

The present investigation of "Studies on high density planting in mango (Mangifera indica L.) cv. Alphonso" was carried out in Regional Horticulture Research and Extension Centre, Dharwad (University of Horticultural Sciences, Bagalkot,) during May - 2016 to June - 2018. The material used, techniques adopted and observations recorded during the course of the investigation are presented in this chapter. Five year old mango orchard cv. Alphonso established during 2011 was selected for the experiment. The pruning was done after harvesting of fruits in 2016 and 2017. Three different mulches were used viz $\mathrm{M}_{1}$ (no mulch), $\mathrm{M}_{2}$ (straw) and $\mathrm{M}_{3}$ (polythene mulch). Four different densities like $2.5 \times 2.5$ $\mathrm{m}$ (1600 plants/ ha), $5.0 \times 2.5 \mathrm{~m}$ (800 plants/ ha), $5.0 \times 5.0 \mathrm{~m}$ (400 plants/ ha) and $7.5 \times 5.0$ m (267 plants/ ha). Each treatment was replicated three times and four plants were chosen from each replication. The experiment was laid out in two Factorial Randomized Block Design. Quality and Bio Chemical parameters recorded during this study viz, TSS was determined by Voisny Erma hand refractometer ( $0^{\circ}$ to $32^{\circ}$ range) and expressed in ${ }^{\circ}$ Brix. Reducing sugar as per the Dinitro Salicylic acid (DNSA) method. The per cent of non-reducing sugar was obtained by subtracting the values of total sugar with reducing sugar and multiply the same with 0.95 as correction factor and expressed in per cent. The total sugar in the sample was estimated by same method as that of reducing sugar after inversion of the non-reducing sugar using dilute hydrochloric acid and expressed in per cent. Titrable Acidity was estimated by titration using standard $\mathrm{NaOH}$ using phenolphthalein indicator. Ascorbic acid content was estimated in mature fruits by 2,6 dichlorophenolindophenol visual titration method. Chlorophyll is extracted in Dimethyl sulphoxide and the absorption at $663 \mathrm{~nm}$ and $645 \mathrm{~nm}$ are read in a spectrophotometer. Carotenoid content was estimated following the method as suggested by Hiscox and Israelstom (1979) and expressed as $\mathrm{mg} \mathrm{g}^{-1}$. Proline content of the leaf was estimated by the method of Bates et al., (1973) and expressed as $\mathrm{mg} \mathrm{g}^{-1}$ fresh weight.

\section{Results and Discussion}

\section{Acidity (\%)}

Pooled data of both the seasons was recorded in the Table 1, the highest acidity was recorded in the plants spaced at $7.5 \times 5.0 \mathrm{~m}$ $(0.53 \%)$ which was on par with the treatment $5.0 \times 2.5 \mathrm{~m}(0.49 \%)$, and the lowest acidity was recorded in $5.0 \times 5.0 \mathrm{~m}(0.46 \%)$. Among the different mulches, the highest acidity in control $(0.51 \%)$ on par with plastic mulch $(0.49 \%)$ and the lowest acidity was recorded in the treatment straw mulch $(0.45 \%)$. In interaction, the treatment $\mathrm{D}_{3} \mathrm{M}_{1}(0.54 \%)$ recorded the highest acidity which was on par with $\left(0.54 \mathrm{D}_{4} \mathrm{M}_{1}(0.53 \%), \mathrm{D}_{2} \mathrm{M}_{1}(0.50 \%)\right.$, $\mathrm{D}_{2} \mathrm{M}_{3}(0.50 \%), \mathrm{D}_{4} \mathrm{M}_{2}(0.50 \%)$ whereas, the lowest acidity was recorded in the treatment $\mathrm{D}_{3} \mathrm{M}_{2}(0.38 \%)$. 


\section{Ascorbic acid (mg per 100 gm)}

Pooled data of both the seasons recorded in Table 1, the maximum ascorbic acid was recorded in the plants spaced at $2.5 \times 2.5 \mathrm{~m}$ (39.60 mg per $100 \mathrm{gm}$ ) which was on par with the treatment $5.0 \times 5.0 \mathrm{~m}(39.30 \mathrm{mg}$ per 100 gm) and the minimum ascorbic acid was recorded in $5.0 \times 2.5 \mathrm{~m}$ (38.82 $\mathrm{mg}$ per 100 gm). Among the different mulches the maximum ascorbic acid content was found in plastic mulch (39.90 mg per $100 \mathrm{gm})$ which was followed by control (39.04 mg per 100 gm) whereas, the minimum was recorded in straw mulch (38.56 mg per $100 \mathrm{gm}$ ). In interaction studies, the treatment $\mathrm{D}_{1} \mathrm{M}_{1}(41.22$ mg per $100 \mathrm{gm}$ ) recorded maximum ascorbic acid which was on par with $\mathrm{D}_{4} \mathrm{M}_{3}(40.47 \mathrm{mg}$ per $100 \mathrm{gm}), \mathrm{D}_{3} \mathrm{M}_{3}(40.13 \mathrm{mg}$ per $100 \mathrm{gm})$, whereas, the minimum ascorbic acid was recorded in the treatment $\mathrm{D}_{1} \mathrm{M}_{2}(37.63 \mathrm{mg}$ per $100 \mathrm{gm})$.

\section{Total soluble solids $\left({ }^{0} \mathrm{~B}\right)$}

The highest total soluble solids in pooled data at different spacing was found in the plants spaced at $7.5 \times 5.0 \mathrm{~m}\left(20.94{ }^{0} \mathrm{~B}\right)$ which was followed by $5.0 \times 5.0 \mathrm{~m}\left(20.29^{0} \mathrm{~B}\right)$ and the lowest total soluble solids was recorded in the treatment $2.5 \times 2.5 \mathrm{~m}\left(19.07{ }^{0} \mathrm{~B}\right)$. Among the different mulches, the highest total soluble solids in plastic mulch $\left(21.59{ }^{0} \mathrm{~B}\right)$ and the lowest total soluble solids was recorded in the treatment control $\left(18.68{ }^{0} \mathrm{~B}\right)$. In interaction, the treatment $\mathrm{D}_{4} \mathrm{M}_{3}\left(23.55{ }^{0} \mathrm{~B}\right)$ recorded the highest total soluble solids which was followed by $\mathrm{D}_{2} \mathrm{M}_{3}\left(21.59{ }^{0} \mathrm{~B}\right), \mathrm{D}_{3} \mathrm{M}_{3}\left(21.44{ }^{0} \mathrm{~B}\right)$ whereas, the lowest total soluble solids was recorded in the treatment $\mathrm{D}_{2} \mathrm{M}_{1}\left(17.90{ }^{0} \mathrm{~B}\right)$.

\section{Total sugar $(\%)$}

Pooled data (2016-18) results of total sugar was found maximum in the spacing $5.0 \times 5.0$ $\mathrm{m}(13.61 \%)$ which was followed by the spacing $7.5 \times 5.0 \mathrm{~m}(13.13 \%)$ and the minimum total sugar was recorded in the treatment $2.5 \times 2.5 \mathrm{~m}(12.72 \%)$. Different mulches showed significant difference, the maximum total sugar was recorded in plastic mulch $(13.37 \%)$ which was followed by straw mulch $(13.04 \%)$ and the minimum total sugar was recorded in the treatment control (12.80 $\%)$. In interaction, the treatment $\mathrm{D}_{3} \mathrm{M}_{3}$ (13.99 $\%)$ recorded maximum total sugar which was on par with $\mathrm{D}_{3} \mathrm{M}_{2}(13.67 \%)$ whereas, the minimum total sugar was recorded in the treatment $\mathrm{D}_{1} \mathrm{M}_{1}(12.34 \%)$.

\section{Reducing sugars (\%)}

The maximum reducing sugars was recorded in the spacing $7.5 \times 5.0 \mathrm{~m}(4.75 \%)$ which was on par with the spacing $5.0 \times 5.0 \mathrm{~m}(4.67 \%)$ and the minimum reducing sugars was recorded in the treatment $5.0 \times 2.5 \mathrm{~m}$ (4.54 $\%)$. Different mulches showed significant difference, the maximum reducing sugars was recorded in plastic mulch $(4.77 \%)$ on par with straw mulch $(4.71 \%)$ and the minimum reducing sugars was recorded in the treatment control $(4.44 \%)$. In interaction, the treatment $\mathrm{D}_{1} \mathrm{M}_{3}(5.12 \%)$ recorded maximum reducing sugars which was on par with $\mathrm{D}_{4} \mathrm{M}_{2}(5.02 \%)$ whereas, the minimum reducing sugars was recorded in the treatment $\mathrm{D}_{3} \mathrm{M}_{1}(4.37 \%)$.

\section{Non reducing sugars (\%)}

Pooled data of both the seasons was recorded in the Table 2. The maximum non reducing sugars was recorded in the spacing $5.0 \times 5.0 \mathrm{~m}$ $(8.49 \%)$ which was followed by the spacing $7.5 \times 5.0 \mathrm{~m}(7.95 \%)$ and the minimum non reducing sugars was recorded in the treatment $2.5 \times 2.5 \mathrm{~m}$ (7.64\%). Different mulches showed significant difference, the maximum non reducing sugars was recorded in plastic mulch $(8.09 \%)$ and the minimum non reducing sugars was recorded in the treatment control $(7.90 \%)$. 
Table.1 Effect of different plant density and different mulches on quality parameters

\begin{tabular}{|c|c|c|c|c|c|c|c|c|c|}
\hline \multirow[t]{3}{*}{ Treatments } & \multicolumn{9}{|c|}{ Quality parameters } \\
\hline & \multicolumn{3}{|c|}{ Acidity $(\%)$} & \multicolumn{3}{|c|}{$\begin{array}{l}\text { Ascorbic acid } \\
\text { (mg per } 100 \text { gm) }\end{array}$} & \multicolumn{3}{|c|}{ TSS $\left({ }^{0} \mathbf{B}\right)$} \\
\hline & \multicolumn{3}{|c|}{ 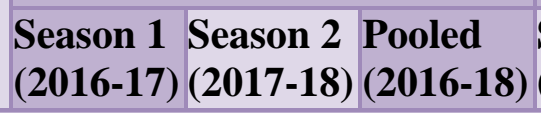 } & \multicolumn{3}{|c|}{$\begin{array}{l}\text { Season } 1 \text { Season } 2 \text { Pooled } \\
(2016-17)(2017-18)(2016-18)\end{array}$} & \multicolumn{2}{|c|}{$\begin{array}{l}\text { Season } 1 \text { Season } 2 \\
(2016-17) \\
(2017-18)\end{array}$} & \multirow[t]{2}{*}{$\begin{array}{l}\text { Pooled } \\
(2016-18)\end{array}$} \\
\hline \multicolumn{9}{|c|}{ Spacing $(\mathbf{D})$} & \\
\hline$D_{1}$ & 0.51 & 0.44 & 0.48 & 39.26 & 40.60 & 39.60 & 18.70 & 19.46 & 19.07 \\
\hline $\mathbf{D}_{2}$ & 0.53 & 0.48 & 0.49 & 38.67 & 38.97 & 38.82 & 19.25 & 20.77 & 20.02 \\
\hline $\mathbf{D}_{3}$ & 0.48 & 0.45 & 0.46 & 39.64 & 38.94 & 39.30 & 19.70 & 20.89 & 20.29 \\
\hline $\mathbf{D}_{4}$ & 0.54 & 0.52 & 0.53 & 39.42 & 38.47 & 38.95 & 20.89 & 20.98 & 20.94 \\
\hline S.Em \pm & 0.01 & 0.02 & 0.02 & 0.29 & 0.53 & 0.20 & 0.19 & 0.35 & 0.25 \\
\hline CD@5\% & 0.04 & 0.05 & 0.06 & NS & 1.55 & 0.60 & 0.56 & 1.03 & 0.73 \\
\hline \multicolumn{10}{|c|}{ Mulching (M) } \\
\hline $\mathbf{M}_{1}$ & 0.52 & 0.51 & 0.51 & 39.48 & 39.10 & 39.04 & 18.81 & 18.54 & 18.68 \\
\hline $\mathbf{M}_{2}$ & 0.49 & 0.43 & 0.45 & 38.99 & 38.14 & 38.56 & 19.46 & 20.50 & 19.97 \\
\hline $\mathbf{M}_{3}$ & 0.54 & 0.47 & 0.49 & 39.28 & 40.50 & 39.90 & 20.64 & 22.53 & 21.59 \\
\hline S.Em \pm & 0.01 & 0.01 & 0.02 & 0.25 & 0.46 & 0.18 & 0.17 & 0.30 & 0.21 \\
\hline CD@5\% & 0.03 & 0.04 & 0.05 & NS & 1.34 & 0.52 & 0.48 & 0.89 & 0.63 \\
\hline \multicolumn{10}{|c|}{ Interaction } \\
\hline $\mathbf{D}_{1} \mathbf{M}_{1}$ & 0.49 & 0.47 & 0.48 & 41.28 & 42.15 & 41.22 & 18.13 & 18.27 & 18.19 \\
\hline $\mathbf{D}_{1} \mathbf{M}_{2}$ & 0.51 & 0.42 & 0.47 & 38.00 & 37.25 & 37.63 & 18.84 & 19.71 & 19.26 \\
\hline $\mathbf{D}_{1} \mathbf{M}_{3}$ & 0.53 & 0.43 & 0.48 & 38.52 & 41.40 & 39.96 & 19.14 & 20.39 & 19.77 \\
\hline $\mathbf{D}_{2} \mathbf{M}_{1}$ & 0.51 & 0.49 & 0.50 & 38.30 & 37.76 & 38.01 & 18.68 & 17.12 & 17.90 \\
\hline $\mathbf{D}_{2} \mathbf{M}_{2}$ & 0.43 & 0.47 & 0.45 & 38.71 & 40.16 & 39.43 & 19.47 & 21.63 & 20.55 \\
\hline $\mathbf{D}_{2} \mathbf{M}_{3}$ & 0.55 & 0.45 & 0.50 & 39.00 & 39.00 & 39.03 & 19.61 & 23.55 & 21.59 \\
\hline $\mathbf{D}_{3} \mathbf{M}_{1}$ & 0.53 & 0.55 & 0.54 & 39.18 & 37.75 & 38.47 & 19.20 & 19.39 & 19.30 \\
\hline $\mathbf{D}_{3} \mathbf{M}_{2}$ & 0.36 & 0.40 & 0.38 & 39.75 & 38.82 & 39.29 & 19.79 & 20.50 & 20.13 \\
\hline $\mathbf{D}_{3} \mathbf{M}_{3}$ & 0.54 & 0.39 & 0.47 & 40.00 & 40.25 & 40.13 & 20.11 & 22.79 & 21.44 \\
\hline $\mathbf{D}_{4} \mathbf{M}_{1}$ & 0.53 & 0.54 & 0.53 & 39.17 & 37.75 & 38.47 & 19.25 & 19.38 & 19.31 \\
\hline $\mathbf{D}_{4} \mathbf{M}_{2}$ & 0.55 & 0.45 & 0.50 & 39.49 & 36.32 & 37.91 & 19.73 & 20.16 & 19.95 \\
\hline $\mathbf{D}_{4} \mathbf{M}_{3}$ & 0.39 & 0.56 & 0.47 & 39.61 & 41.33 & 40.47 & 23.69 & 23.41 & 23.55 \\
\hline S.Em \pm & 0.02 & 0.03 & 0.03 & 0.51 & 0.92 & 0.35 & 0.33 & 0.61 & 0.43 \\
\hline CD@5\% & 0.06 & 0.08 & 0.09 & 1.49 & 2.69 & 1.04 & 0.97 & 1.78 & 1.26 \\
\hline
\end{tabular}

D3- $5.0 \times 5.0 \mathrm{~m}(400$ plants/ ha $)$

D4- $7.5 \times 5.0 \mathrm{~m}$ ( 267 plants/ ha) 
Table.2 Effect of different plant density and different mulches on quality parameters

\begin{tabular}{|c|c|c|c|c|c|c|c|c|c|}
\hline \multirow[t]{3}{*}{ Treatments } & \multicolumn{9}{|c|}{ Quality parameters } \\
\hline & \multicolumn{3}{|c|}{ Total sugar $(\%)$} & \multicolumn{3}{|c|}{ Reducing sugars $(\%)$} & \multicolumn{3}{|c|}{ Non reducing sugars (\%) } \\
\hline & \multicolumn{3}{|c|}{$\begin{array}{l}\text { Season } 1 \text { Season } 2 \text { Pooled } \\
(2016-17)(2017-18)(2016-18)\end{array}$} & \multicolumn{3}{|c|}{$\begin{array}{l}\text { Season } 1 \text { Season } 2 \text { Pooled } \\
(2016-17)(2017-18) \\
(2016-18)\end{array}$} & \multicolumn{3}{|c|}{$\begin{array}{l}\text { Season } 1 \text { Season } 2 \text { Pooled } \\
(2016-17)(2017-18) \\
(2016-18)\end{array}$} \\
\hline \multicolumn{10}{|c|}{ Spacing (D) } \\
\hline $\mathbf{D}_{1}$ & 12.73 & 12.70 & 12.72 & 4.54 & 4.61 & 4.57 & 7.59 & 7.69 & 7.64 \\
\hline $\mathbf{D}_{2}$ & 12.80 & 12.80 & 12.80 & 4.69 & 4.42 & 4.54 & 7.71 & 7.98 & 7.84 \\
\hline $\mathbf{D}_{3}$ & 13.60 & 13.62 & 13.61 & 4.84 & 4.50 & 4.67 & 8.32 & 8.66 & 8.49 \\
\hline $\mathbf{D}_{4}$ & 13.10 & 13.17 & 13.13 & 4.83 & 4.68 & 4.75 & 7.86 & 8.04 & 7.95 \\
\hline S.Em \pm & 0.17 & 0.11 & 0.11 & 0.05 & 0.05 & 0.04 & 0.04 & 0.06 & 0.07 \\
\hline CD@5\% & 0.49 & 0.33 & 0.32 & 0.15 & 0.15 & 0.13 & 0.12 & 0.19 & 0.22 \\
\hline \multicolumn{10}{|c|}{ Mulching (M) } \\
\hline $\mathbf{M}_{1}$ & 12.80 & 12.81 & 12.80 & 4.43 & 4.43 & 4.44 & 7.96 & 7.94 & 7.95 \\
\hline $\mathbf{M}_{2}$ & 13.01 & 13.06 & 13.04 & 4.82 & 4.61 & 4.71 & 7.77 & 8.03 & 7.90 \\
\hline $\mathbf{M}_{3}$ & 13.36 & 13.36 & 13.37 & 4.94 & 4.60 & 4.77 & 7.89 & 8.31 & 8.09 \\
\hline S.Em \pm & 0.14 & 0.10 & 0.09 & 0.04 & 0.04 & 0.04 & 0.04 & 0.06 & 0.06 \\
\hline CD@5\% & 0.42 & 0.29 & 0.25 & 0.13 & 0.13 & 0.11 & 0.11 & 0.16 & 0.19 \\
\hline \multicolumn{10}{|c|}{ Interaction } \\
\hline $\mathbf{D}_{1} \mathbf{M}_{1}$ & 12.35 & 12.32 & 12.34 & 4.40 & 4.47 & 4.44 & 7.55 & 7.45 & 7.50 \\
\hline $\mathbf{D}_{1} \mathbf{M}_{2}$ & 12.80 & 12.77 & 12.78 & 4.62 & 4.24 & 4.43 & 7.69 & 8.10 & 7.89 \\
\hline $\mathbf{D}_{1} \mathbf{M}_{3}$ & 13.05 & 13.03 & 13.05 & 5.14 & 5.11 & 5.12 & 7.53 & 7.52 & 7.52 \\
\hline $\mathbf{D}_{2} \mathbf{M}_{1}$ & 12.78 & 12.80 & 12.79 & 4.39 & 4.44 & 4.41 & 7.97 & 7.95 & 7.95 \\
\hline $\mathbf{D}_{2} \mathbf{M}_{2}$ & 12.53 & 12.56 & 12.55 & 4.82 & 4.50 & 4.66 & 7.32 & 7.65 & 7.48 \\
\hline $\mathbf{D}_{2} \mathbf{M}_{3}$ & 13.10 & 13.04 & 13.07 & 4.85 & 4.26 & 4.55 & 7.84 & 8.33 & 8.09 \\
\hline $\mathbf{D}_{3} \mathbf{M}_{1}$ & 13.17 & 13.18 & 13.18 & 4.34 & 4.40 & 4.37 & 8.40 & 8.34 & 8.37 \\
\hline $\mathbf{D}_{3} \mathbf{M}_{2}$ & 13.65 & 13.69 & 13.67 & 4.98 & 4.47 & 4.72 & 8.23 & 8.76 & 8.50 \\
\hline $\mathbf{D}_{\mathbf{3}} \mathbf{M}_{3}$ & 13.97 & 13.98 & 13.99 & 5.21 & 4.63 & 4.93 & 8.33 & 8.85 & 8.60 \\
\hline $\mathbf{D}_{4} \mathbf{M}_{1}$ & 12.90 & 12.82 & 12.90 & 4.56 & 4.39 & 4.47 & 7.92 & 8.00 & 7.96 \\
\hline $\mathbf{D}_{4} \mathbf{M}_{2}$ & 13.07 & 13.23 & 13.15 & 4.82 & 5.22 & 5.02 & 7.84 & 7.61 & 7.73 \\
\hline $\mathbf{D}_{\mathbf{4}} \mathbf{M}_{3}$ & 13.31 & 13.39 & 13.35 & 5.10 & 4.42 & 4.76 & 7.81 & 8.51 & 8.15 \\
\hline S.Em \pm & 0.29 & 0.20 & 0.15 & 0.09 & 0.09 & 0.08 & 0.07 & 0.11 & 0.13 \\
\hline CD@5\% & 0.85 & 0.58 & 0.47 & 0.26 & 0.27 & 0.23 & 0.21 & 0.33 & 0.38 \\
\hline
\end{tabular}

D1- $2.5 \times 2.5 \mathrm{~m}(1600$ plants/ ha $)$

D2- $5.0 \times 2.5 \mathrm{~m}(800$ plants/ ha $)$

$\mathrm{M}_{1^{-}}$Control

$\mathrm{M}_{3}$ - Plastic mulch

$\mathrm{M}_{2}$ - Straw mulch

D3- $5.0 \times 5.0 \mathrm{~m}(400$ plants/ ha)

D4- $7.5 \times 5.0 \mathrm{~m}(267$ plants/ ha) 
Table.3 Effect of different plant density and different mulches on Bio Chemical parameters

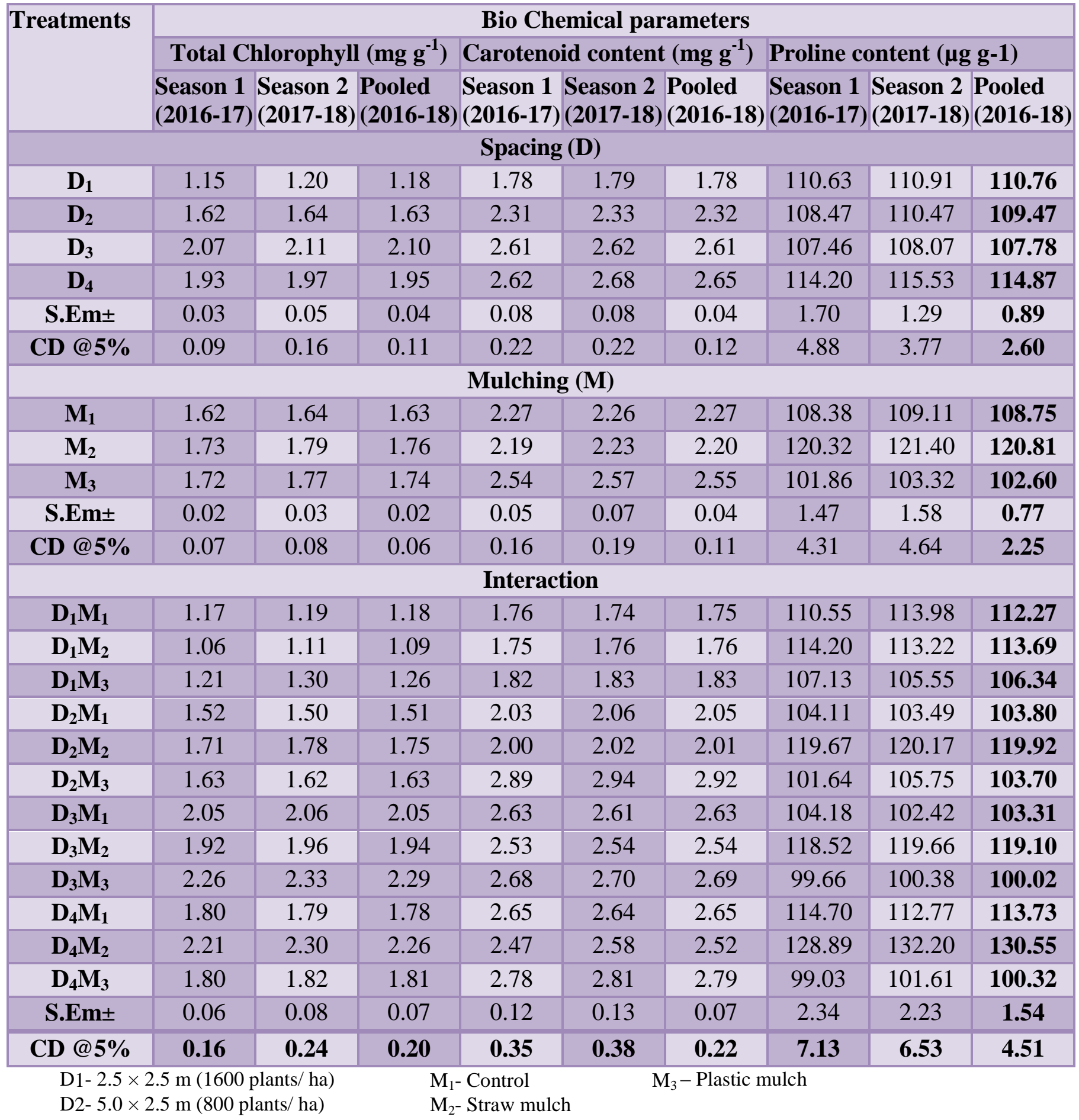

D3- $5.0 \times 5.0 \mathrm{~m}(400$ plants/ ha)

D4- $7.5 \times 5.0 \mathrm{~m}(267$ plants/ ha $)$ 
In interaction, the treatment $\mathrm{D}_{3} \mathrm{M}_{3}(8.60 \%)$ recorded maximum non reducing sugars which was on par with the treatment $\mathrm{D}_{3} \mathrm{M}_{2}$ $(8.50 \%)$ and $\mathrm{D}_{3} \mathrm{M}_{1}(8.37 \%)$ whereas, the minimum non reducing sugar was recorded in the treatment $\mathrm{D}_{2} \mathrm{M}_{2}(7.48 \%)$.

\section{Total chlorophyll}

Pooled data of both the seasons found that the maximum total chlorophyll was recorded in the plants spaced at $5.0 \times 5.0 \mathrm{~m}\left(2.10 \mathrm{mg} \mathrm{g}^{-1}\right)$ which was followed by the spacing $7.5 \times 5.0$ $\mathrm{m}\left(1.95 \mathrm{mg} \mathrm{g}^{-1}\right)$ and the minimum total chlorophyll was recorded in $2.5 \times 2.5 \mathrm{~m}$ (1.18 $\left.\mathrm{mg} \mathrm{g}^{-1}\right)$. With respect to different mulches, the maximum total chlorophyll was recorded in straw mulch $\left(1.76 \mathrm{mg} \mathrm{g}^{-1}\right)$ on par with plastic mulch $\left(1.74 \mathrm{mg} \mathrm{g}^{-1}\right)$ and the minimum total chlorophyll was recorded in control $(1.63 \mathrm{mg}$ $\left.\mathrm{g}^{-1}\right)$. Whereas in interaction, the maximum total chlorophyll was recorded in $\mathrm{D}_{3} \mathrm{M}_{3}(2.29$ $\mathrm{mg} \mathrm{g}^{-1}$ ) which was on par with the treatment $\mathrm{D}_{4} \mathrm{M}_{2}\left(2.26 \mathrm{mg} \mathrm{g}^{-1}\right)$ and the minimum total chlorophyll was recorded in $\mathrm{D}_{1} \mathrm{M}_{1}(1.09 \mathrm{mg}$ $\mathrm{g}^{-1}$ ) (Table 3).

\section{Carotenoid content ( $\left.\mathrm{mg} \mathrm{g}^{-1}\right)$}

Pooled data of both the seasons exhibited, the highest carotenoid content was recorded in the plant spacing $7.5 \times 5.0 \mathrm{~m}\left(2.65 \mathrm{mg} \mathrm{g}^{-1}\right)$ which was on par with the treatment $5.0 \times 5.0$ $\mathrm{m}\left(2.61 \mathrm{mg} \mathrm{g}^{-1}\right)$ and the lowest carotenoid content was recorded in $2.5 \times 2.5 \mathrm{~m}(1.78 \mathrm{mg}$ $\left.\mathrm{g}^{-1}\right)$. Among the different mulches, the highest carotenoid content was recorded in plastic mulch $\left(2.55 \mathrm{mg} \mathrm{g}^{-1}\right)$ which was followed by control $\left(2.27 \mathrm{mg} \mathrm{g}^{-1}\right)$ and the lowest carotenoid content was recorded in the treatment straw mulch $\left(2.20 \mathrm{mg} \mathrm{g}^{-1}\right)$.

In interaction, the treatment $\mathrm{D}_{2} \mathrm{M}_{3}\left(2.92 \mathrm{mg} \mathrm{g}^{-}\right.$ $\left.{ }^{1}\right)$ recorded the highest carotenoid content which was on par with $\mathrm{D}_{4} \mathrm{M}_{3}\left(2.79 \mathrm{mg} \mathrm{g}^{-1}\right)$, $\mathrm{D}_{3} \mathrm{M}_{3}$ (2.69 $\mathrm{mg} \mathrm{g}^{-1}$ ) whereas, the lowest carotenoid content was recorded in the treatment $\mathrm{D}_{1} \mathrm{M}_{1}\left(1.75 \mathrm{mg} \mathrm{g}^{-1}\right)$.

\section{Proline content $\left(\mu g^{-1}\right)$}

Pooled data revealed, the maximum proline content was recorded in the plants spaced at $7.5 \times 5.0 \mathrm{~m}\left(114.87 \mu \mathrm{g} \mathrm{g} \mathrm{g}^{-1}\right)$ which was followed by the spacing $2.5 \times 2.5 \mathrm{~m}$ (110.76 $\left.\mu \mathrm{g} \mathrm{g}^{-1}\right)$ and the minimum proline content was recorded in $5.0 \times 5.0 \mathrm{~m}\left(107.78 \mu \mathrm{g} \mathrm{g}^{-1}\right)$. With respect to different mulches, the maximum proline content was recorded in straw mulch $\left(120.81 \mu \mathrm{g} \mathrm{g}^{-1}\right)$ and the minimum proline content was recorded in plastic mulch $(102.60$ $\left.\mu \mathrm{g} \mathrm{g}^{-1}\right)$. Whereas in interaction the maximum proline content was recorded in $\mathrm{D}_{4} \mathrm{M}_{2}(130.55$ $\mu \mathrm{g} \mathrm{g}^{-1}$ ) which was followed by the treatment $\mathrm{D}_{2} \mathrm{M}_{2}\left(119.92 \mu \mathrm{g} \mathrm{g}^{-1}\right), \mathrm{D}_{3} \mathrm{M}_{2}\left(119.10 \mu \mathrm{g} \mathrm{g}^{-1}\right)$ and the minimum proline content was recorded in $\mathrm{D}_{3} \mathrm{M}_{3}\left(100.02 \mu \mathrm{g} \mathrm{g}^{-1}\right)$.

The interactive effect of spacing and mulching had a positive and significant influence on quality of fruits. Plants spaced at $5.0 \times 5.0 \mathrm{~m}$ from control recorded the highest titratable acidity. Whereas, plastic mulch recorded the highest total sugar and nonreducing sugars in the same spacing. Plants spaced at $7.5 \times 5.0 \mathrm{~m}$ with plastic mulch recorded the highest total soluble solids. Plants spaced at $2.5 \times 2.5 \mathrm{~m}$ from control recorded the highest ascorbic acid content whereas, plastic mulch recorded the highest reducing sugars in same spacing. Mulching was fond to be superior in all densities compared to control plants whereas, low density planting given best results with respect to quality of fruits. This may be due to the fact that plastic mulch might have caused increase in light reflectivity from the surface of reflective mulches which allows greater photosynthetic activity in the plants. Low density planting opens the canopy for better aeration and light distribution which resulted in the production of good quality fruits Kim et 
al., (2008). This is in accordance with Bal and Singh (2011) ${ }^{[3]}$.

Findings of this research recorded the maximum total chlorophyll in plants spaced at $5.0 \times 5.0 \mathrm{~m}$ with use of plastic mulch Plants spaced at $7.5 \times 5.0 \mathrm{~m}$ spacing from control recorded the maximum chlorophyll-b whereas, straw mulch recorded the maximum proline content in same spacing. Plants spaced at $5.0 \times 2.5 \mathrm{~m}$ with plastic mulch showed the maximum carotenoid content. The interactive effect of spacing and mulching had a positive influence on bio-chemical parameters.

This may be due to the fact that plastic mulch might have increased soil temperature, increased $\mathrm{CO}_{2}$ level and increase respiration rate, these are responsible for creating favourable microclimate around plants, which induced better bio-chemical aspects (Kumar et al., 2008) ${ }^{[4]}$. Plastic mulch could improve leaf photosynthetic, as well as absorption of each drop of water and nutrients thereby, enhanced metabolic activities within plant during the period of growth and fruit development process (Singh and Dhaliwal., 2007) $)^{[5] .}$

\section{References}

Anonymous 2014, Effect of mulch and irrigation level by drip on water use efficiency and yield of water melon. $10^{\text {th }}$ AGRESCO report, CAET, JAU, Junagadh.

Bal, J. S. and Singh, G. S., 20011, A note on effect of selective pruning of late flowers on size and quality of fruit in Ber cultivars. Haryana J. Hort. Sci., 32 (3 and 4): 232-233.

Biswas, S. K., Akanda, A. R., Rahman, M. S. and Hossain, M. A., 2015, Effect of drip irrigation and mulching on yield, wateruse efficiency and economics of tomato. Pl. Soil Env., 61 (3) : 97-102.

Kumar, S. P., Reddy, Y. N. and Hari, S. D., 2008, Effect of pruning on production of new shoots, subsequent growth and flowering of mango cv. Baneshan. $J$. Res., ANGRAU, Hyderabad, 31 (1): 2630.

Singh, G. and Dhaliwal, G. S., 2007, Effect of different pruning levels on fruit yield and quality of guava (Psidium guajava L.) cv. Sardar. Haryana J. Hort. Sci., 33 (1 and 2): 83-84.

\section{How to cite this article:}

Sagar, B.S., S.I. Athani, S. Raghavendra, Mallikarjun Awati, J.B. Gopali, T.B. Allolli, Kulapati Hipparagi and Revanappa. 2019. Influence of Different Plant Densities and Mulches on Quality and Bio Chemical Parameters of Mango (Mangifera indica L.) cv. Alphonso. Int.J.Curr.Microbiol.App.Sci. 8(06): 3361-3368. doi: https://doi.org/10.20546/ijcmas.2019.806.399 